Section Editor

Robert C. Griggs, MD
Editors' Note: In this week's WriteClick, ethics expert Bernat furthers the discussion about what it means to be conscious and outlines the difference between the $\mathrm{Yu}$ et al. diagnosis of "unresponsive wakefulness syndrome" vs "minimally conscious state" and the roles that EEG fMRI and neurologic examination play in these assessments. Burke et al. comment on Benarroch's article and highlight that further HCN channel investigation may shed some light on the mechanisms behind benign familial neonatal epilepsy. Richard Tenser extends the finding by Tan et al. that acyclovir-resistant herpes simplex virus may have contributed to the pathophysiology of encephalitis in the authors' patients.

Megan Alcauskas, MD, and Robert C. Griggs, MD

PATIENTS WITH UNRESPONSIVE

WAKEFULNESS SYNDROME RESPOND TO THE PAIN CRIES OF OTHER PEOPLE

James L. Bernat, Lebanon, NH: Yu et al. ${ }^{1}$ reported additional cases of patients diagnosed in a vegetative state (unresponsive wakefulness syndrome) by clinical criteria. However, they showed fMRI or processed EEG responses indicating awareness, and therefore these patients should be diagnosed correctly as in a minimally conscious state. These cases and similar previous cases show that the neurologic examination alone may, in some cases, be insensitive to detect the presence of awareness. The medical and ethical importance of this finding has been emphasized in numerous publications over the past 6 years. ${ }^{2-4}$

The impact of functional neuroimaging in showing the limitations of the neurologic examination to detect awareness is reminiscent of the earlier impact of DNA genetic studies in showing the limitation of the clinical phenotypic classification of neurogenetic syndromes.

The investigators should collect all the cases in which the neurologic examination has been found inadequate to assess awareness and contrast those with the majority of cases in which the clinical examination was accurate. Perhaps there are common features of the clinically misdiagnosed cases that could inform our understanding of awareness with and without responsiveness.

(C) 2013 American Academy of Neurology
WriteClick: Editor's Choice

1. Yu T, Lang S, Vogel D, et al. Patients with unresponsive wakefulness syndrome respond to the pain cries of other people. Neurology 2013;80:345-352.

2. Coleman MR, Davis MH, Rodd JM, et al. Toward the routine use of brain imaging to aid the clinical diagnosis of disorders of consciousness. Brain 2009;132:2541-2552.

3. Wilkinson DJ, Kahane G, Horne M, Savulescu J. Functional neuroimaging and withdrawal of life-sustaining therapy from vegetative patients. J Med Ethics 2009;35:508-511.

4. Bernat JL. Current controversies in states of chronic unconsciousness. Neurology 2010;75(suppl 1):S33-S38.

\section{HCN CHANNELS: FUNCTION AND CLINICAL IMPLICATIONS}

David Burke, James Howells, Susan E. Tomlinson, Sydney, Australia: Dr. Benarroch ${ }^{1}$ highlighted the function of HCN channels. Studies of axonal excitability using threshold tracking techniques allow $\mathrm{HCN}$ function to be quantified indirectly in human peripheral nerve in vivo. ${ }^{2}$ These physiologic studies may clarify the activity of different voltage-dependent channels expressed on the studied axons, even in CNS disease. For example, abnormalities have been shown in benign familial neonatal epilepsy, a condition due to mutation of the KCNQ2 gene encoding $\mathrm{K}_{\mathrm{v}} 7.2$. The abnormalities in axonal excitability were those appropriate for loss of slow $\mathrm{K}^{+}$channel function. ${ }^{3}$ Current protocols for studying the accommodation to hyperpolarization produced by $\mathrm{HCN}$ currents now use strong long hyperpolarizing currents as conditioning stimuli to alter membrane potential. ${ }^{4}$ This has allowed further insight into the nature of $\mathrm{HCN}$ current in human myelinated axons; specifically, that $\mathrm{HCN} 1$ is probably expressed on large myelinated axons, but that isoform expression may differ for myelinated afferent and efferent axons. ${ }^{5}$ In defined patient groups with epilepsy, these techniques could help clarify whether there is abnormal HCN function. In neuropathic pain, the situation is less certain because the action potentials of small nociceptive afferents can only be characterized with microneurography.

(C) 2013 American Academy of Neurology

1. Benarroch EE. HCN channels: function and clinical implications. Neurology 2013;80:304-310.

2. Bostock H, Cikurel K, Burke D. Threshold tracking techniques in the study of human peripheral nerve. Muscle Nerve 1998;21:137-158. 
3. Tomlinson SE, Bostock $\mathrm{H}$, Grinton B, et al. In vivo loss of slow potassium channel activity in individuals with benign familial neonatal epilepsy in remission. Brain 2012;135: 3144-3152.

4. Tomlinson S, Burke D, Hanna M, Koltzenburg M, Bostock H. In vivo assessment of HCN channel current (Ih) in human motor axons. Muscle Nerve 2010;41:247-256.

5. Howells J, Trevillion L, Bostock H, Burke D. The voltage dependence of Ih in human myelinated axons. J Physiol 2012;590:1625-1640.

\section{ATYPICAL MANIFESTATIONS AND POOR OUTCOME OF HERPES SIMPLEX ENCEPHALITIS IN THE IMMUNOCOMPROMISED}

Richard B. Tenser, Hershey, PA: In the article by Tan et al., ${ }^{1}$ atypical illness and poor outcome of HSV encephalitis in immunocompromised patients was likely due to their immune status, and possibly also to antiviralresistant mutant HSV. Acyclovir and related antivirals are phosphorylated by the HSV-encoded thymidine kinase (TK) to the active antiviral state.

However, during HSV infections, mutants arise that are acyclovir resistant primarily because they lack viral TK activity $(\mathrm{TK}-)$ and do not phosphorylate acyclovir. $^{2}$ In non-immunosuppressed HSV-infected individuals treated with acyclovir, wild-type TK + HSV is inhibited by acyclovir, and the small amounts of TK - HSV that develop are likely controlled by the immune system. However, in immunocompromised individuals, while wild-type TK + HSV is inhibited by acyclovir, TK - mutants likely multiply.

We used an isotope plaque assay to estimate proportions of $\mathrm{TK}-$ and $\mathrm{TK}+\mathrm{HSV}$ in lesion swabs from an immunocompromised patient treated with acyclovir. ${ }^{3}$ TK - HSV does not replicate well in nondividing cells but does in replicating cells. In immunocompromised patients, ${ }^{1}$ it is suggested that during the period of acyclovir treatment, TK- HSV probably replicated, more likely in glial cells than in neurons. Presumptive TK- HSV may have contributed to the atypical clinical course of these patients.

Author Response: Avindra Nath, Bethesda, MD: I thank Dr. Tenser for his comments and for agreeing that acyclovir-resistant HSV may have played a role in the pathophysiology of encephalitis in these patients. C) 2013 American Academy of Neurology

1. Tan IL, McArthur JC, Venkatesan A, Nash A. Atypical manifestations and poor outcome of herpes simplex encephalitis in the immunocompromised. Neurology 2012;79:2125-2132.

2. Sarisky RT, Quail MR, Clark PE, et al. Characterization of herpes simplex viruses selected in culture for resistance to penciclovir or acyclovir. J Virol 2001;75:1761-1769.

3. Westheim AI, Tenser RT, Marks JG. Acyclovir resistance in a patient with chronic mucocutaneous herpes simplex infection. J Am Acad Dermatol 1987;17:875-880.

\section{Neurology ${ }^{\circledR}$ WriteClick: Join the Debate!}

The editors encourage comments about recent articles through WriteClick:

Go to www.neurology.org and click on the "WriteClick" tab at the top of the page. Responses will be posted within 72 hours of submission.

Before using WriteClick, remember the following:

- WriteClick is restricted to comments about studies published in Neurology within the last eight weeks

- Read previously posted comments; redundant comments will not be posted

- Your submission must be 200 words or less and have a maximum of five references; reference one must be the article on which you are commenting

- You can include a maximum of five authors (including yourself) 


\section{Neurology}

\section{HCN Channels: Function and clinical implications}

David Burke, James Howells and Susan E. Tomlinson

Neurology 2013;81;513-514

DOI 10.1212/01.wnl.0000433163.22224.2c

This information is current as of July 29, 2013

\section{Updated Information \&} Services

References

Permissions \& Licensing

Reprints including high resolution figures, can be found at: http://n.neurology.org/content/81/5/513.2.full

This article cites 5 articles, 1 of which you can access for free at: http://n.neurology.org/content/81/5/513.2.full\#ref-list-1

Information about reproducing this article in parts (figures,tables) or in its entirety can be found online at:

http://www.neurology.org/about/about_the_journal\#permissions

Information about ordering reprints can be found online:

http://n.neurology.org/subscribers/advertise

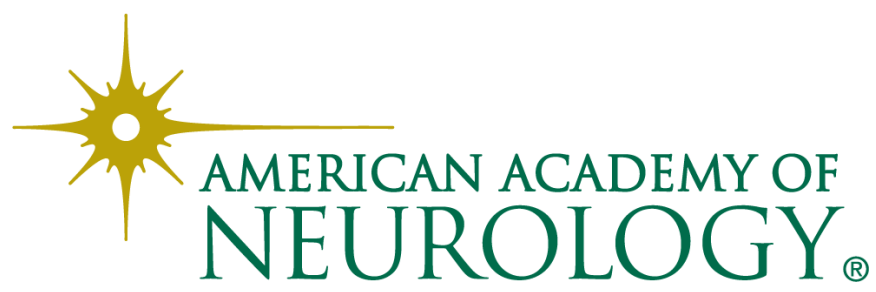

